\title{
"WE ARE NOT JUST PATRIOTS OF A COUNTRY, BUT CITIZENS OF THE PLANET": CHILDREN'S IDENTITY NEGOTIATIONS IN JULIA ALVAREZ'S RETURN TO SENDER
}

\author{
Andrea Fernández García, Universidad de Oviedo \\ Email: andreafg87@hotmail.com
}

\begin{abstract}
According to Manuel Castells, the present global era is characterized by a dialectical tension between a globalist imagination of unbounded space ("space of flows") and an essentialist conception of space as ruptured and divided into bounded entities ("space of places"). These conflicting tendencies are depicted in Julia Alvarez's Return to Sender (2009), which is told from the dual perspectives of a Mexican immigrant girl and an American boy who struggle for self-definition in a global context. The present paper aims at analyzing how both children navigate through this paradox, focusing on their dilemmas of identity and belonging and the strategies devised to overcome them. Keywords: Globalization, children, illegal immigration, identity, exclusion.
\end{abstract}

Título en español: "No sólo somos patriotas de un país, sino también ciudadanos/as del planeta": Las negociaciones identitarias de los/as niños/as en Return to Sender, de Julia Álvarez

Resumen: Tal y como sostiene Manuel Castells, la actual era global se caracteriza por una tensión dialéctica entre una visión globalista del espacio como un ente sin límites ("espacio de los flujos") y una concepción esencialista que presenta el espacio como un ente dividido en partes claramente delimitadas ("espacio de los lugares"). Julia Álvarez retrata estas visiones antagónicas en su novela Return to Sender (2009), que ofrece la doble perspectiva de una niña inmigrante mexicana y un niño estadounidense que tratan de definir su propia identidad en un contexto global. Este artículo pretende analizar cómo estos personajes negocian tal paradoja, prestando especial atención a sus dilemas de identidad y a las estrategias empleadas para resolverlos.

Palabras clave: Globalización, niños/as, inmigración ilegal, identidad, exclusión. 
Sometimes it's only in the world of story that we understand the human side of political and loaded issues

$(\text { Alvarez 2009: } 1)^{70}$

\section{SPACE OF FLOWS VS. SPACE OF PLACES}

As Manuel Castells contends (1996: 421-423), globalization is characterized as leading to a dialectical tension between the global flows of goods, people and information (the "space of flows") and the historically rooted spatial organization of human experience (the "space of places"). Political scientist Sara Kalm (2005: 14-19) explains that these opposing and conflicting dynamics of globalization are rooted in two different conceptualizations of space: first, a globalist imagination of de-territorialization and unbounded space; and second, an essentialist conception of space as divided into bounded and unchanging places with their own internally generated authenticity. Many scholars seem to imply that the tension between these geopolitical imaginations lies at the heart of the resurgence of exclusivist nationalisms and localisms in different parts of the world (see, for example, Harvey 1989, 1996; Massey 1994).In this sense, geographer David Harvey notes how one response to time-space compression has been the sense of anxiety that leads to people withdrawing into some notions of a settled place that can be defined against and defended from others, reason why he deems place as almost necessarily reactionary $(1989,1996)$. Geographer Kevin Robins goes beyond this last remark as he suggests that these problematical perceptions of place might have been triggered by the arrival of the "periphery" at the "core," and not so much by the influx of people and goods from core countries (in Massey 1995: 52). The core-periphery paradigm that Robins uses states that the globe consists of core developed areas (i.e. Western countries) that have spread their influence to the less developed periphery (the rest of the world). Even if I concur with Castells (1996: 174) and Appadurai (1996: 31 ) that the power restructurings brought about by globalization (e.g. how Saudi Arabia is now considered a core in terms of energy distribution) cannot be accounted for by the core-periphery framework, I believe Robins is right in his main thesis. One only needs to examine contemporary immigration policies across Western areas to validate his argument. Looking at the European Union, expert in migration law Elspeth Guild identifies a "typology of European inclusion and exclusion," which serves as an organizing principle around which territorial and social inclusion and exclusion are drawn (in Aas 2013: 29). This typology posits citizens of the European Union as the most desirable immigrants, followed by citizens of other Western nations, while the least desirable are those from countries mostly located in Asia, Africa, Middle East and Latin America(in Aas 2013: 29-30). The Unites States has a similar hierarchy of immigrant desirability, as evidenced by its immigration policies, which "have generally reflected the desires, interests and purposes of Americans of European descent, thus resulting in the United States having a very high percentage of

70 This statement, made by Julia Alvarez herself, is referenced in the "Reader's Guide" to Return to Sender. This guide is included at the end of the novel and is numbered separately from the story, running from 1 through 2. 
Americans of European descent” (Nevins 2002: 122). In his discussion of Guild's typology, criminologist Katja Franko Aas argues that it is based on a "pre-established racialized, colonial, ranking" (2013: 30) inasmuch as it places people from predominantly white societies on top of the hierarchy, while relegating the designated Others to the very bottom. Yet if Aas only discusses the European case, my contention is that the hierarchy that is present in the United States also reproduces the colonial ranking attributable to the European Union, for it has historically aimed at prioritizing the interests of European Americans over those of other populations.

These attitudes towards immigrants from developing ${ }^{71}$ countries are fueled by the belief that they "pose a socioeconomic and ethno-cultural threat to Western societies," as Ariane Chebel d'Appollonia argues in Frontiers of Fear: Immigration and Insecurity in the United States and Europe (2012: 13).This perceived threat has become especially acute in the aftermath of the 9/11 terrorist attacks, resulting in the strengthening of immigration restrictions and xenophobic attitudes against those immigrants already in Western countries (d'Appollonia 2012: 1-4). Interestingly, nonetheless, OECD statistics confirm that the flow of people from developing countries to the West has been on the increase since the beginning of 2000s (OECD 2012: 57-59), which inevitably questions the efficacy of the post-9/11 regulations to stop migration.

Let us now concentrate on Mexican immigration to the United States, which is one of the largest flows of migrant workers in the contemporary world (Escobar Latapí 2008: 179; Rosenblum et al.2012: 1). The history of this migration flow is long, dating back to 1848, when the Treaty of Guadalupe-Hidalgo established the Rio Grande as the national border between Mexico and the US, leaving a Mexican population stranded in an alien country, though with firmly established ties on the opposite bank. According to Massey et al. (2002: 25 ), because the border area was scarcely populated in the $19^{\text {th }}$ century, we cannot "speak of 'international migration' between Mexico and the United States until the $20^{\text {th }}$ century," a time when Mexicans began moving to the US in significant numbers. Following Saskia Sassen's insights on US immigration patterns towards Mexico (1996), it can be argued that the emergence of political and economic links between the two nations, together with overpopulation and economic stagnation in the sending country, created conditions for the initiation of large-scale Mexico-US immigration.

The development of railroads linking Mexico and the United States in the early $20^{\text {th }}$ century and later the Bracero Program (1942-1964) were among the first initiatives that contributed to increases in the number of Mexican immigrants. Both projects came into being

71 In this paper I use the term "developing countries" as a shorthand expression embracing more than a hundred low-income and middle-income states located in Africa, Middle East, Asia, Latin America and the Caribbean. While acknowledging that these countries do not share the same developmental, political, social, cultural or economic characteristics, I justify the use of the term under discussion by the fact that it is employed by most governments of these countries themselves, as well as by global institutions, such as the World Bank and the United Nations (www.worldbank.org/www.un.org). But this is not to suggest that this term in unproblematic. On the one hand, there is no universally accepted definition of what constitutes a developing country, and on the other hand, many scholars agree that this term implies "the inferiority of a 'developing country' compared to the 'developed country"' (White et al. 2011: 2). Despite these shortcomings, I primarily use this concept because in my view there are no better alternatives. 
as a result of a series of agreements between the two nations. The first made it easier for Mexicans to move to the Northern border and also led to a sharp increase in communication and trade, which made Mexico "an economic satellite of the United States" (Henderson 2011: 16). For its part, the Bracero Program imported temporary farm workers from Mexico so as to help fill the farm labor shortages that developed as American soldiers were shipped overseas to combat in World War II (Laham 2000: 63). The termination of this program is considered as a major factor for a significant increase in illegal immigration from Mexico since 1964 (Laham 2000: 63). Mexicans who had moved to the United States legally as part of the Bracero Program now had no alternative but to do so illegally, in order to continue working in American agriculture (Laham 2000: 63). Subsequent increases in the number of legal and illegal Mexican immigrants occurred in the current era of globalization and neoliberalism, which emphasizes privatization, deregulation and trade liberalization. The enthusiasm for these neoliberal values led to the signing of a North American Free Trade Agreement (NAFTA) in 1994. This agreement obliged its three signatories (the US, Canada and Mexico) to carry out internal reforms and to eliminate tariffs to free trade, holding out an alluring promise: The proponents of NAFTA were confident that the agreement "would lift Mexico out of poverty, putting a definitive end to the immigration problem" (Henderson 2011: 118). However, working and living conditions have deteriorated since then, propelling more Mexican citizens than ever to head north to participate in the relatively strong US economy (Henderson 2011: 136-139). In this sense, it must be noted that the transformation of the occupational and income structure in the United States -itself a result of neoliberal globalization-has created an expanding supply of low-wage jobs, particularly in the service sector, facilitating the absorption of regular and, above all, irregular immigrants (Sassen 1996: 225-226). These circumstances have allowed the United States to attract and benefit from a much-needed supply of cheap and undocumented (therefore rightless) Mexican workers, thus turning a blind eye to its own immigration laws (Condon and Sinha 2003: 73). This lax attitude towards illegal immigration contrasts with the discrimination suffered by most undocumented Mexicans living in the United States. Indeed, not only are they vulnerable to racial prejudice, not to mention labor exploitation, but they are constantly threatened with deportation (Howell 2014: 164-168; Pyke 2014: 205-206), leading to a complex situation that unveils the dialectic tension between space of flows and space of places.

This paradoxical state of affairs is depicted in Return to Sender, a children's novel by Dominican-American writer Julia Alvarez. This literary work tells the story of Mari, an undocumented Mexican girl who struggles over place and belonging in a racist environment that paradoxically relies on Mexican labor for its survival. In addition to presenting readers with this problematic situation, Alvarez portrays how the conflicting dynamics of globalization affect the development of an Anglo-American boy from Vermont. Thus, Mari's story parallels that of Tyler, who doubts whether or not the flow of undocumented Mexicans to Vermont jeopardizes his place-bound identity. This concern arises as a result of the increasing arrival of Mexican immigrants to a place rated as "one of whitest states in the nation" (Clark and Teachout 2012: 178), as I shall discuss later on.

My intention, then, is to analyze how both characters navigate through these challenges in an attempt to shed light on the experiences of children, which several scholars identify as an understudied area of recent scholarship of globalization (see, for example, 
Suárez-Orozco 2001). In "In Her Own Words: A Conversation with Julia Alvarez" (2009: 3-10), a section which follows the Reader's Guide in Return to Sender, Alvarez explains that the goal of this novel is indeed to give visibility to the inner conflicts that Mexican and Vermont children were facing between 2005 and 2006 in that Northern state. In this sense, she claims to have seen Mexican children living in fear of deportation, whereas Vermont youngsters felt confused by the increasing arrival of Mexican families to that state. This situation brings to fore social issues that are experienced by many young people in different parts of the world. The most recent example is that of thousands of Mexican and Central American youngsters who are crossing the Mexico-United States border alone, as reported by different media over the last few months (see, for example, Park 2014; Martinez and Hurtado 2014; and Ferreira 2014). It could therefore be argued that not only does Return to Sender deal with very relevant and current issues but also contributes to drawing attention to the often ignored relationship between children and globalization, thus opening possible avenues for further discussion.

\section{EXPERIENCING GLOBALIZATION: EXCLUSION, IDENTITY AND BELONGING}

Alvarez's novel is focalized through Mari, a Mexican girl who moves from North Carolina to Vermont, and Tyler, a Vermont boy whose parents have hired Mari's father and uncles to work in their dairy farm. The third-person chapters about Tyler alternate with Mari's lengthy unmailed letters and diary entries. This polyphonic layering of voices captures the experiences of Mexican and Anglo-American children in a globalized context, on which I will elaborate in this section. More precisely, I shall focus on Mari's experiences of exclusion and the dilemmas of identity and belonging encountered by both characters, dilemmas triggered by the conflicting dynamics of globalization shortly accounted for above.

In Geographies of Exclusion: Society and Difference in the West (2002/1995) David Sibley presents a theory of exclusion that can be used to analyze Mari's marginalization in the US society, a discriminatory practice motivated by her status as a member of an ethnic minority. Sibley's groundbreaking insights on exclusion are indebted to Julia Kristeva's theory of abjection, which refers to the individual's attempt to distance oneself from objects that represent undesirable characteristics (2002/1995: 8-11). In Western societies, he argues, ethnic minorities are often regarded as abject and outside the mainstream (2002/1995: 49). This perception is key to understanding their exclusion in Western countries, which is discursively represented as the "purification of space" (2002/1995: 77-87). Sibley defines this notion as a process of social control through which a dominant social group constructs socio-spatial boundaries that contribute to the marginalization of ethnic minorities and other social groups judged as abject (2002/1995: 77-87). As I shall show, boundaries play an important part in Mari's struggle for self-definition, operating at different spatial levels, and each corresponding to a particular site of exclusion: the nation, the locality and the home. Sibley views these sites as potential spaces of exclusion for those deemed as deviant and, far from treating them as discrete problems, he demonstrates how, to some extent, one has effects on the other (2002/1995: 90). As for Mari's marginalization, these spaces of exclusion also condition one another. Thus, we will see how, for instance, the nation's 
nativism not only informs discriminatory attitudes at the local level but also provides cues for behavior in Mari's family as they relate to their domestic environment.

Nativism is generally defined as a political and social force aimed at protecting the interests of certain established inhabitants of a nation, a force that has repeatedly manifested itself in countries such as France, Germany and the United States, to name a few. ${ }^{72}$ In the latter case, nativism is deeply rooted in notions of white supremacy that deem Anglo-Saxons to be natives of the United States (Pérez Huber et al. 2008: 42), even though they derive from immigrant stock themselves. This force fuels the xenophobic attitudes encountered by many Mexican immigrants, who are considered to be the main targets of nativist attacks in contemporary American society (Pérez Huber et al. 2008: 40). The impact of a nativist discourse on Mexican immigrants is perfectly exemplified in different episodes of discrimination that affect Mari. In this sense, I would like to focus on a discriminatory event that takes place at the school bus, where two of Mari's classmates, Ronnie and Clayton, insult her with very bad words: "These boys say the very same things that the kids in North Carolina say about me being an 'illegal alien' who should go back to where she came from" (2009: 65). According to Law scholar Catherine Dauvergne, the pejorative term "illegal alien" conceals the pervasive power of prosperous nations to exclude the Others from within (2008: 17). More precisely, she contends that the labeling of people as "illegal" is part of a defensive pattern commonly used by Western countries to build walls around themselves when their borders cannot keep outsiders out (2008: 17). In other words, strategies like this serve Western nations well to "purify" social space, that is, to assert a place-bound identity that excludes the "defiled" and "defiling" Others, to use Sibley's terms (2002/1995).

Nonetheless, I shall argue that the insults thrown at Mari by her classmates might not only be motivated by the desire to exclude foreigners from the nation, but also by a purely local concern, thus showing how the nation and the locality as sites of exclusion reinforce one another. In order to demonstrate this, it is necessary to consider Vermont's racial geography. In "In Her Own Words: A Conversation with Julia Alvarez" (2009: 3-10), Alvarez refers to the setting of the novel as "lily-white Vermont," pointing to the lack of racial diversity in that area. Even if this situation began to change with the arrival of Mexican immigrants in the 2000s, recent official statistics still reveal a striking contrast: 94 percent of Vermont's population in 2013 was Caucasian, whereas only 2 percent was Hispanic (World Population Statistics n.d.). Geographer Robert M. Vanderbeck argues that this lack of racial diversity is central to how the state has been represented and represents itself (2006: 641). He contends that Vermont has historically been imagined as "one of the last remaining places of authentic Yankee whiteness" (2006: 641, my emphasis).This category, Vanderbeck argues, has generally referred to independent white Anglo-Saxon Protestants who cherish notions of liberty, democracy and equality (2006: 646). Thus, Vermont's imaginary geography is clearly implicated in the exclusion of those people who do not fit the above-mentioned description. In this sense, Vanderbeck notes that the targets of exclusion have changed throughout time: from Jews, Irish and Italians to US Southerners (2006: 646-650). The latter have been rejected because of their slaveholding and segregationist past, which is defined against the progressive character associated with Vermont (2006: 649). In this regard, Van-

72 For an overview of nativism in Western Europe and America, see Lucassen 2005 and Schrag 2010. 
derbeck argues that the assumptions about the liberal character of this Northern state have complicated the recognition of discrimination against those people who do not fall within any category of whiteness (2006: 650). Importantly, the exclusionary power of Vermont's imaginary geography as it applies to ethnic minorities is perfectly illustrated in the novel under study, as shown by the sign that reads "TAKE BACK VERMONT" (2009: 191) on Mr. Rossetti's lawn. This demand expresses Mr. Rossetti's wish to protect Vermont's white essence against the increasing arrival of Mexicans to that state's dairy farms. Return to Sender is indeed set at a time when a great number of farmers began to hire undocumented workers from farming areas in Mexico (mainly Chiapas and Yucatan) to boost Vermont's farming industry, which drives the state's economy. This is the case with Tyler's family, the Paquettes, who decide to employ Mari's father and uncles in view of the difficulty of finding local help that might be willing to work for long hours, with almost no days off, showing how the rightless status of undocumented workers makes them the perfect candidates for jobs that locals find unappealing, even abusive. Interestingly, the shortage of local farm labor is identified by Radel et al. (2010: 189) as the major factor stimulating the ongoing migration of undocumented Mexican workers to Vermont. This increasing flow of migrants inevitably calls into question the state's myths about its alleged racial homogeneity. A more dynamic view of this Northern state is nonetheless at odds with those Vermonters who see place as bounded, an example of which is Mr. Rossetti. Turning to the episode of the school bus, my contention is that the same fixed view about Vermont that Mr. Rossetti holds could also underlie Ronnie and Clayton's exclusionary attitude. This contention gains strength when considering the importance of whiteness in Alvarez's novel, which is not only reflected in Mr. Rossetti's explicit demands but also in Mari's awareness that her physical appearance might raise suspicion in an all-white area.

In addition to feeling excluded from the host society, Mari finds herself trapped at home. This situation inevitably refutes the "home as haven" thesis, which sees domestic environments as sources of comfort in a world replete with dangers and conflicts (Sibley 2002/1995: 93). Mari's feelings of entrapment in her own home are motivated by the threats posed by la migra and her father's patriarchal values. On the one hand, because the border patrol might catch Mexicans easily in white Vermont, Mari and her family are left with no choice but to stay at home most of the time, fearing that la migra might be behind any expected noise they hear, as she recounts:

After that call, we were all very nervous as we always are when we hear news of someone being nabbed by la migra. It is as if a cloud hangs over our family and darkens our world [...]. So when the doorbell rang, we all jumped. For one thing, in the four months we had been living here, that doorbell had never rung [...]. At first, none of us even knew what it was. One ring, and then another, another. It reminded me of the priest ringing the independence bell in México to wake up the people from freedom. But since we feared it was la migra, this ringing was more the sound of the end of our family's freedom. (2009: 101)

The sound of the doorbell and recent news of other deportations make Mari and her family sense that they are in constant danger of being caught by the border patrol. This feeling informs the rules and instructions that Mari's father, Mr. Cruz, gives to her daughters. Thus, the female protagonist and her little sisters, Luby and Ofie, are not allowed to leave 
their house alone or send letters to her relatives for the fear that they will be apprehended. I shall argue that these severe restrictions reflect how the power of the nation to determine who belongs to the American society invades the home, thereby demonstrating how the nation as a site of exclusion conditions the domestic sphere.

On the other hand, male dominance and the expectation of female domesticity and premarital chastity, values embedded in the complementary gender roles of machismo and marianismo respectively (Gil and Vazquez 1996: 6-8), subordinate Mari to her father at home. Due to her mother's absence, the female protagonist is required to act as a surrogate mother for Ofie and Luby and, because she is on the threshold of adolescence, she is not allowed to be alone with Tyler in her own house. These gender restrictions, together with the deportation threat dynamic, render the home as a site of exclusion for Mari, allowing us to dismiss the "home as haven" thesis. This thesis has been overtly contested by a wide range of feminist scholarship for it overlooks the stratified relationships that subordinate women to men in the private realm (see, for example, Domosh and Seager 2001; McDowell 2003/1999). In my view, the patriarchal dynamics that regulate women's domestic performance and the threats posed by la migra allow us to characterize The Cruces' house in accordance with Sibley's notion of the home as a "locus of power relations" (2002/1995: 92), a notion that successfully captures the polar tensions between family members.

It could then be argued that Mari is denied the right to lead a comfortable life in Vermont even if her family has been encouraged to settle in that Northern state so as to work in its farming industry. This situation, which reflects the dialectical tension between space of flows and space of places, is not an isolated one in Vermont. In this sense, Radel et al. argue that the survival of Vermont's farming industry has come to depend on Mexican workers, whose illegal status urges employers to house them in enclosed spaces of farm buildings, forcing them to live like prisoners (2010: 190). This paradoxical state of affairs serves to exemplify what Carty and Macias call a "schizophrenic" attitude towards unauthorized Mexican immigration, which is best reflected in the message "we need your labor but you are not welcome as citizens" (2014: 7). Thus, the demonization of illegal Mexican immigration goes hand in hand with continuing recruitment of Mexican workers.

This contradictory attitude mirrors Mari's cultural schizophrenia, that is, her inability to determine where she belongs. The exclusion she faces in her daily life makes it very difficult for her to a find a place she can call home. In "Place and Identity: a Sense of Place," feminist geographer Gillian Rose contends that immigrants who experience exclusion in the host countries usually develop a sense of place that does not evoke belonging at all (1995: 96). This means that for immigrants the host nation is often infused with negative feelings, leading to a sense of displacement. So is the case with Mari, who thinks of the United States as a place that turns its back on Mexican immigrants: "I feel like Mary and Joseph at all the posada stops when they're turned away [...]. No room for us in this country" (2009: 143). The biblical episode she mentions recounts how Mary and Joseph were denied shelter on their way to Bethlehem, an episode that bears some resemblance to her situation in the United States. Self-defined as a Catholic, the female protagonist usually refers to biblical episodes like this or prays to the Virgin of Guadalupe, which brings her closer to Mexico. However, Mari feels she cannot relate to her country of origin completely either. The gender restrictions her family imposes on her explain to a great extent the distance that has grown 
between the female protagonist and Mexico, as she points out in a letter addressed to her relatives in Las Margaritas: "Abuelito and Abuelote and Abuelota and Tío Felipe and toda la familia, I certainly hope that Papá is wrong about how you do not allow girls and boys to be special friends. Because if this is so, I hate to say, but just like my sister Ofie, I would not want to live in México" (2009:210). Because she has grown up in North Carolina, Mari has developed a frame of reference that differs in some ways from her parents' and, as a consequence, she finds many of their values obsolete, as is the case with their gendered codes of behavior. In a similar vein, she criticizes the fact that her parents never allowed her and her sisters to go trick-or-treating when they were living in North Carolina:

As for us, no matter how hard we explained the American tradition, my sisters and I were not permitted to go around begging for treats. 'That is a lack of respect,' Mamá explained. 'With so many beggars who really need alms!' Sometimes, even if I had been born in México, I felt a huge desert stretching between my parents and who I was becoming. (2009: 102)

Here, the female protagonist acknowledges that she is becoming someone completely different from her parents, who come to epitomize a part of Mexico that she dislikes. This separation, together with her inability to relate to the United States due to the discrimination she suffers, lead her to a state of profound alienation, which she will in fact overcome, as I shall demonstrate in the next section.

Mari's frustration at not being able at finding a place of her own goes parallel to Tyler's struggle to determine if hiring illegal immigrants jeopardizes his own group affiliation. This quandary arises after Mr. Paquette has a tractor accident that leaves him unable to work, an event that leads the family to employ Mexican workers, following the example of many of their fellow farmers. However, even if Tyler knows that his farm depends on Mexican labor for its survival, he cannot help but feel suspicious about the newcomers: "Good thing his mom added that last part about coming to help us. Tyler hates to admit it, but after September 11 , he's a little scared of strangers from other countries who might be plotting to destroy the United States of America. It'd be worse than losing the farm, losing his whole country! Where would he and his family go?" (2009: 42). As can be seen, Tyler's suspicion about foreign workers is fuelled by the post- $9 / 11$ paranoia. The tragedy of the $9 / 11$, which is widely perceived as a "national trauma" (Doss 2010: 120), has since evoked a strong anxiety regarding the safety of the nation, thus giving rise to a patriotic fervor that seeks to protect the country from racialized others. ${ }^{73}$ Tyler's strong patriotism is indeed expressed through his reluctance to accept the newcomers, a defensive attitude aimed at securing the US identity against the feared Others.

Mrs. Paquette asks Tyler to leave aside his concerns about foreign workers and encourages him to get to know Mari, Luby and Ofie, which he grudgingly accepts to do. His first encounter with the Mexican girls (who happen to be the first Mexicans he has ever met) is indeed marked by his reluctance to open himself to the newcomers. As a matter of fact,

73 While there is no denying that the primary targets of the post- 9/11 "war on terror" were Muslim and Arab-looking terrorists, the backlash within the United States has also affected other racialized groups, including Latinos/as. For more information on the impact of the "war on terror" on Latinos/as, see Bender 2002. 
he finds everything the girls say or do strange, and even criticizes some aspects of their culture, such as the Catholic tradition of naming girls after the Virgin Mary: "So you're all María Something,' Tyler observes smartly. In Spanish class Ms. Ramírez said María was a real popular name in Spanish. But this is ridiculous. Even the cows without names get their very own ear-tag numbers" (2009: 44). Yet this lack of respect for the cultural Other is temporarily gone when Mari and Tyler find something in common: their love for astronomy. Thus, they develop a friendship which is broken again after Tyler finds out that only Luby and Ofie are legally in the United States. As illegal immigration goes against the laws of the country, the male protagonist refuses to be friends with Mari and tells her: "I'd rather lose the farm than not be loyal to my country" (2009: 70). This statement reveals the national conviction that patriots have to conform to the laws of the country, which instills in Tyler a fear that he will be considered a traitor if he hosts illegal immigrants. Consequently, the male protagonist decides to put an end to his friendship with Mari scarcely after it had begun, thus prioritizing his place-bound identity over his farm and whom till that time had been his friend.

Given the fact that Mari is illegally in the country, Tyler starts to think of her as a criminal, going as far as to spy on her through his telescope "in case she is up to something illegal" (2009: 79). Criminality is indeed an image frequently linked to Latinos/as (Lee 2000; Bender 2002, 2003; O'Brien 2008), and continuously reproduced by the dominant culture in such a way that it has come to join the set of beliefs that Antonio Gramsci called "common sense" (in Omi and Winant 1994: 67). Gramsci coined this term to refer to the generally held assumptions about social life that are cleverly imposed on people without their conscious recognition in an attempt to support the existing social order. Drawing on this concept, sociologists Michael Omi and Howard Winant (1994) develop the notion of "racial formation," which denotes the ways racial categories and their apparent correlates (stereotypes) become part of the common sense. Political scientist Steven W. Bender (2002, 2003), who studies the relationship between stereotypes and the maltreatment of Latinos/ as under American law, contends that the widespread association between this racialized group and lawbreaking is based on two main beliefs: first, Latinos/as are thought to have sneaked into the country illegally, thus giving rise to the pejorative label "illegal alien"; and second, young men in particular are assumed to be gang members and/or drug dealers. Bender explains that for many scholars these beliefs, together with images of Latinos/as as lazy and greasy, "originated at least as early as needed to justify this country's territorial designs on the Southwest, culminating in the US-Mexico War" (2003: 12). Since then these unflattering conceptions have been sustained and fueled by the unceasing fear resulting from continued Latino/a immigration to the United States (Bender 2003: 13). In particular, the assumption that all Latinos/as are undocumented is epitomized in Return to Sender by Ronnie and Clayton, who call Mari "illegal" without knowing if she has legal documentation or not. On the other hand, discovering the truth about the girl's status allows Tyler to further criminalize her as he starts to keep an eye on her to protect the prevailing social order.

Nonetheless, even if the male protagonist seems determined to turn his back on Mari forever, the knowledge he gains following his decision to break his relationship with the immigrant girl makes him feel dubious about what patriots and criminals are. More precisely, 
the lessons about global justice and equality that he internalizes lead Tyler to realize that the identity categories he believed to be clear-cut are now blurred: ${ }^{74}$

Tyler feels confused. It's as if he's lost in some dark wood inside his own head. Seems like a lot of his treasured ideas and beliefs have gone into a tailspin recently. It used to be he knew what was right, what was wrong, what it meant to be a patriot or a hero or a good person. Now he's not sure. Take his dad, who has to be the most patriotic American Tyler has ever known. But even Dad has had to employ Mexicans without papers to help his farm. (2009: 187)

As the excerpt above shows, the male protagonist seems to question whether or not he is less of a patriot if he hosts illegal immigrants. This inner conflict, as well as Mari's inability to determine where she belongs, get to be solved by actively engaging in a process of remaking identities.

\section{REMAKING IDENTITIES: TOWARDS A COSMOPOLITAN PERSPECTIVE}

A wide range of scientific literature shows that globalization has caused major global problems, such as the increasing inequalities within and between groups of people, countries and regions, inequalities that are very often racialized. Sociologist Saskia Sassen presents the global city as a site where such inequalities reach record levels (2013/1991, 1998). These disparities are seen in the amount of resources that are allocated to different city areas. Thus, whereas the downtowns of global cities receive massive investments in real estate and telecommunications, low-income city areas (which are usually the home to ethnic minorities) are starved for resources (Sassen 1998: xxvi-xxvii). While there is no denying that globalization has generated problems like this, I would argue that it has also led to the context in which individuals increasingly see themselves as "world citizens" with duties and responsibilities within an interconnected world. In this section I hope to demonstrate that the children characters under scrutiny manage to remake their identities by engaging with a global ethic of mutual recognition and justice embedded in the highly contested concept of world/global citizenship. This remaking process is to be understood as a crucial stage in the psychological maturation of both characters, which is one of the main focuses of the novel.

Generally speaking, the concept of global citizenship (which is mostly used as an equivalent to cosmopolitanism) defines people who identify themselves with a global community that has a nascent set of values and practices. Whereas most discourses on global citizenship agree on this general definition, there are other aspects (e.g. whether this concept is more about duties or more about rights) that are amenable to different readings and interpretations. As we shall see in this section, the model of global citizenship that permeates Return to Sender is made up of three main ideas, also shared by Nigel Dower (2002) and Kazuco Otsu(1997), who develop their theories of global citizenship in the contexts of international relations and education respectively: first, people are members of a wider, global and universal whole; second, all human beings are global citizens in virtue

74 In the next section I will elaborate on the lessons of global equality that help Tyler interrogate his earlier views on identities. 
of rights and duties which we all have as human beings; and third, among our duties as global citizens is that of overcoming our continuous tendency to marginalize diversity in pursuit of homogeneity and helping others preserve/acquire their fundamental rights. I am aware of the fact that the duty that prompts global citizens to help people attain freedom and other rights dangerously evokes the imperialist projects of some Western nations (such as the US) that use the protection of rights as a pretext for intervention in other countries. In this novel, however, this duty is devoid of any intention to control other people and places, as we will see.

The above-mentioned ideas were preached by Tyler's late grandfather, and nowadays by Mr. Bicknell, the school teacher, both of whom help the male protagonist dismantle his narrow views on patriots and criminals. In fact, Tyler gives his agreement to the hiring of undocumented workers after he is told how his grandfather approached immigration:

Actually, dear, your uncle Larry's had Mexicans for a while over at his place," Grandma explains. "Your dad wouldn't hear of it, until, of course, the accident made him reconsider. But when your uncle Larry told us, you know what Gramps said? He said, 'We Paquettes came down from Canada back in the 1880s. Nobody but nobody in America got here -excepting the Indianswithout somebody giving them a chance.' That's what he said" [...]. "So, honey, I think Gramps would understand. (2009: 87)

His grandfather's conviction that immigrants should be given a chance correlates one of the ideas defended by world citizens, that is, people have the responsibility to help others pursue their rights, in this case their right to a better life. This family lesson marks the beginning of Tyler's transformation into a global citizen, as he abandons his anti-immigrant feelings for a commitment to help undocumented workers pursue a better life in America.

Tyler's new attitude opens the way to a new relationship between the two children protagonists, a relationship based on the principles of mutual recognition and respect, again echoing the global ethics embedded in the concept of global citizenship that Alvarez puts forward. This process of mutual recognition entails what bell hooks calls "repositioning" (1992: 177) or what Alfonso de Toro refers to as "the recognition of the Other as the different-other with same rights" (2006: 29). The former develops the notion "repositioning" in the context of interracial relationships to describe the process of occupying the subject position of the Other to dehegemonize the self and subvert practices of racism. The latter's conceptualization constitutes the main tenet of "Latin-Culture," a model of coexistence for hybrid societies that is built on William Luis, Gloria Anzaldúa and Guillermo Gómez Peña's respective insights on cultures and identities. This model is developed with the aim of devising new strategies for social coexistence in a world characterized by the loss of the "natural" link between cultures and the social and geographical territories. Thus, "Latin-Culture" proposes that a simple encounter with a different-other demands the negotiation and recognition of an irreducible difference in a common space. Summarizing, hooks and de Toro's conceptualizations share three fundamental aspects that redefine the relationship between Tyler and Mari: the establishment of a cross-cultural dialogue, the recognition of differences in a common space and the rejection of fixed identities. 
The male protagonist begins to reposition himself as he learns about Mari's culture and the complexities of immigrant families. Indeed, he comes to understand the girl's feelings of displacement after she teaches him the meaning of the Mexican song "La Golondrina," which evokes the loneliness and nostalgia felt by Mexican expatriates: "So this is what the three Marías feel, so far from home! And to think that Tyler has made them feel even more lonesome with his unfriendliness and spying. He wishes he had words that would let them know he is sorry, that they do belong here" (2009: 91). In addition, he comes to understand Mari's deep fears that la migra might separate her from her little sisters, who are American citizens. Thus, Tyler gains a deeper understanding of the human side of illegal immigration, which enables him to gradually depart from the racist narratives that criminalize undocumented immigrants. On the other hand, he also learns to respect Mexican traditions like Las Posadas and the Three Kings Day, which contrast starkly with his previous critique of Mari's cultural background.

Despite the repositioning process Tyler has initiated, he still has some reservations regarding immigrants, as he refuses to publicly acknowledge how hard Mari's family is working on his farm for the fear that others might discover that his family is breaking the law. This reaction infuriates Mari, who feels that Tyler still considers her family as criminals who should be kept underground. However, the boy overcomes these final reservations thanks to Mr. Bicknell, whose ideas about cosmopolitanism and equality are crucial for Tyler to see immigrant labor as paramount for the development of Vermont and the United States. This important step in Tyler's transformation occurs after he listens to Mr. Bicknell's speech against racist attitudes in the community, a speech he delivers to a town meeting in an attempt to convince the attendees to reject a motion against undocumented workers and their employers. The teacher talks people into disapproving the proposal by reminding $\mathrm{Mr}$. Rossetti, the motion's main advocate, and the rest of the attendees of their immigrant past:

My point, Mr. Rossetti, with all due respect, is that Rossetti is an Italian name [...]. I know, I know. Your family's been here forever, since the 1880s, when Vermont needed cheap labor to work on the marble and granite quarries in Proctor and Barre [...]. What if Vermonters had raised an outcry about these foreigners endangering our sovereign state and nation? Many of us wouldn't be here. Plus we'd have missed out on great builders, hard workers, and terrific pizza [...]. And one more thing, Mr. Rossetti [...]. Not only would we Vermonters have missed out on this rich heritage had we booted out all those Italians, we wouldn't have you here today to keep us all on our toes [...]. I'm serious. Mr. Rossetti is passionate about his country. Whether or not we share his ideas, we would do well to learn that much from him [...]. But the bottom line is that this country, and particularly this state, were built by people who gave up everything in search of a better life, not just for themselves, but for their families. Their blood, sweat, and tears formed this great nation. (2009: 190-191)

Here, the school teacher emphasizes the fact that Vermont and the United States have been shaped by migration processes. Thus, rather than seeing places as homogeneous entities that must be maintained pure in the face of globalization, Mr. Bicknell suggests that Vermont and the United States have to be seen as constructed out of social relations that stretch well beyond these two places, a view that echoes Massey's notion of a "progressive sense of place" (1994: 151). By this, Massey suggests that what gives a place its specificity is not 
some long internalized history but the fact that is formed out of a particular constellation of relations that are never local. This approach to places goes in line with Mr. Bicknell's thoughts of people as being part of a wider network, a viewpoint perfectly reflected in his famous statement "we are all citizens of one planet, indivisible with liberty and justice for all" (2009: 72), which he usually repeats in his lectures. Drawing on this globalist ethic, he urges the meeting attendees to respect immigrants' rights to freedom and well-being, while also praising Mr. Rossetti's passionate love for his country, thereby showing that cosmopolitanism and patriotism can be considered mutually inclusive aspects. These globalist-oriented lessons have a strong impact on the meeting attendees, who reposition themselves in favor of illegal immigrants, who go from being criminals to becoming crucial agents of historical progress. These globalist views also have a profound effect on Tyler, who passes a note to Mari expressing the following: "Thank you for helping save our farm" (2009: 191, emphasis in the original). This reaction demonstrates that he no longer views immigrants as criminals, but as valuable and hard-working people who contribute to building Vermont and the United States, thus putting forward a more fluid conceptualization of places.

The female protagonist also internalizes the globalist lessons taught by Mr. Bicknell, as she is gradually able to see herself as belonging to the world despite the constant threats of deportation. Besides, she comes to embrace the globalist ethic referred to in this section, as she becomes more determined to defend her own rights and help others preserve theirs. Proof of this is her growing commitment to denounce the violation of immigrants' rights, which reaches its peak after her parents are unfairly arrested as part of the Operation "Return to Sender." This operation, which lends its name to the novel under study, was an initiative by the Immigration and Customs Enforcement (ICE) Agency to raid and deport "criminal aliens," such as convicted felons and gang members. Mari's mother, who reappears after being missing for most part of the story, is taken to prison because of an alleged relationship between her and the smugglers who abducted her in the Mexico-United States border. On the other hand, Mr. Cruz is imprisoned for confronting the border patrol agents when they were arresting his wife for a crime she did not commit. Mari decides to register this unfair situation in her diary in an attempt to raise awareness about the abuse of immigrants' rights and thus open the door for possible changes in this respect: "So I'm going to write down exactly what happened. If I am finally taken away to jail, I will leave you, dear Diary, to tell the world the whole truth of what we have been through" (2009: 265). It is worth-noting that Mari's duties as a global citizen are not limited to the demands for justice that she registers in her diary, but are extended to include real actions performed in real places. The best example of this can be found in Mari's defense of her parents' rights at the Homeland Security Office, an action she performs with the help of Tyler, who also wants Mr. and Mrs. Cruz to be released from jail. The female protagonist tells the clerk at the Office everything related to her mother's abduction and argues that, because of their illegal status, her father could not report her mother's disappearance, thus drawing attention to the lack of protection for immigrants. Her determination to tell their real story contributes to releasing her parents from prison. However, she cannot prevent all the family from being deported to Mexico.

The letters Mari and Tyler exchange following deportation demonstrate that they have managed to resolve their inner conflicts. They think of themselves "not just [as] patriots of a country, but citizens of a planet" (2009: 317), meaning that their acceptance of world 
citizenship is compatible with other levels of identity and community. Tyler considers himself to be Vermonter and American, while Mari states that she has two homes, one in Las Margaritas and one in "a special farm in the rolling hills of Vermont" (2009: 314). However, their conceptualization of place-identities is far from being homogeneous and exclusive. Instead these are viewed as being shaped by their global connections as much as by their local character, a conceptualization in accordance with Massey's notion of a "progressive sense of place," which views places as dynamic, in process and inclusive. In fact, Tyler no longer sees the increasing migration flows of today's world as endangering his place-identity, for identities are precisely the result of global processes and interconnections. On the other hand, Mari and Tyler's self-definition as global citizens is based on the interconnections that bind people together in pursuit of justice and equality for all. This self-perception serves Tyler well to reposition himself on illegal immigration and assume responsibility for helping others attain their fundamental rights, whereas for Mari it means to have a place in the world and undertake a commitment to the struggle for opportunities for illegal immigrants. Nonetheless, even if they have come to embrace a model of global citizenship that views rights as dependent on membership in humanity, they know that Mari will not be able to claim place-rights in America unless she does it legally, thus acknowledging that the granting of rights will still be up to the nation in question.

At this point then, it could be said that Return to Sender features two empowered and empowering children characters that successfully navigate through the challenges posed by the combination of a globalist outlook that justifies the increasing mobility that characterizes our current times and a roots-oriented facet that emphasizes the need to secure national homogeneity against the defiled and defiling Others. This paper has proved how both children overcome these challenges by engaging with a globalist ethic that fiercely contests traditional notions of identities that exclude people from the possibility of belonging and enjoying the most basic rights.

\section{REFERENCES}

AAS, K. F. 2013. "The Ordered and the Bordered Society: Migration Control, Citizenship and the Northern Penal State." The Borders of Punishment: Migration, Citizenship, and Social Exclusion. Eds. K. F. Aas and M. Bosworth. Oxford: Oxford UP. 21-39.

ALVAREZ, J. 2009. Return to Sender. New York: Yearling.

APPADURAI, A. 1996. Modernity at Large: Cultural Dimensions of Globalization. Minneapolis: Minnesota UP.

BENDER, S. W. 2002. "Sight, Sound, and Stereotype: The War on Terrorism and its Consequence for Latinas/os.” Oregon Law Review 81: 1153-1178.

2003. Greasers and Gringos: Latinos, Law and the American Imagination: New York and London: New York UP.

CARTY, V. AND K. MACIAS. 2014. "Immigration on the U.S.-Mexico Border: The Impact of Neoliberal Policies and U.S. Foreign Policy on Migration Flows." Scholars 
and Southern Californian Immigrants in Dialogue: New Conversations in Public Sociology. Eds. V. Carty, T. Woldemikael and R. Luévano. Lanham: Lexington Books. 3-20.

CASTELLS, M. 1996. The Information Age: Economy, Society and Culture. Volume 1. The Rise of a Network Society. Oxford: Blackwell.

CLARK, S. AND W. TEACHOUT. 2012. Slow Democracy: Rediscovering Community, Bringing Decision Making Back Home. Vermont: Chelsea Green Publishing.

CONDON, B. AND T. SINHA. 2003. Drawing Lines in Sand and Snow: Border Security and North American Economic Integration. Armonk: Sharpe.

D'APPOLLONIA, A. C. 2012. Frontiers of Fear: Immigration and Insecurity in the United States and Europe. New York: Cornell UP.

DAUVERGNE, C. 2008. Making People Illegal: What Globalization Means for Migration and Law. Cambridge: Cambridge UP.

DE TORO, A. 2006. "Globalization - New Hybridities - Transidentites - Transnations: Recognition - Difference.” New Hybridities: Societies and Cultures in Transition. Eds. F. Heidemann and A. de Toro. Hildesheim: Georg Olms Verlag. 19-38.

DOMOSH, M. AND J. SEAGER. 2001. Putting Women in Place. Feminist Geographies Make Sense of the World. New York and London: The Guildford Press.

DOSS, E. 2010. Memorial Mania: Public Feeling in America. Chicago: Chicago UP.

DOWER, N. 2002. “Global Citizenship: Yes or No?” Global Citizenship: A Critical Introduction. Eds. N. Dower and J. Williams. New York: Routledge. 30-40.

ESCOBAR LATAPÍ, A. 2008. "Mexican Policy and Mexico-U.S. Migration.” Mexico-U.S. Migration Management: A Binational Approach. Eds. A. Escobar Latapí and S. F. Martin. Plymouth: Lexington Books. 179-216.

FERREIRA, R. 2014. “De Centroamérica al infierno de Estados Unidos.” El Mundo. 13 Oct. 2014.

http://www.elmundo.es/america/2014/07/01/53b30d47ca47418e278b456d.html.

GIL, R. M.AND C. I. VAZQUEZ. 1996. The Maria Paradox: How Latinas Can Merge Old World Traditions with New World Self-Esteem. New York: G. P. Putnam's Sons.

HARVEY, D. 1989. The Condition of Postmodernity. Oxford: Blackwell.

1996. Justice, Nature and the Geography of Difference. Cambridge: Blackwell.

HENDERSON, T. J. Beyond Borders: A History of Mexican Migration to the United States. Malden: Wiley-Blackwell.

HOOKS, B. 1992. Black Looks: Race and Representation. London: Turnaround.

HOWELL, A. J. 2014. "Discrimination and Barriers." Undocumented Immigrants in the United States. Ed. A. Ochoa O’Leary. Santa Barbara: ABC-CLIO. 164-168. 
KALM, S. 2005. "Migration, Control Policies as Spatial Organization - Mobility, Power and Geopolitical Imaginations." Academy for Migration Studies in Denmark. 2 Feb. 2014.http://www.amid.dk/pub/papers/AMID_39-2005_Kalm.pdf.

LAHAM, N. 2000. Ronald Reagan and the Politics of Immigration Reform. Westport: Praeger.

LEE, C. K. W. 2000. "Race and Self-Defense: Towards a Normative Conception of Reasonableness." Critical Race Theory: The Cutting Edge. Eds. R. Delgado and J. Stefancic. Philadelphia: Temple UP. 204-210.

LUCASSEN, L. 2005. The Immigrant Threat: The Integration of Old and New Migrants in Western Europe since 1850. Chicago: University of Illinois Press.

MARTINEZ, M. AND J. HURTADO. 2014. "Central American Immigrant Parents Agonize when Child Crosses Border Alone.” CNN U.S. 13 Oct. 2014. http://www. cnn.com/2014/06/21/us/central-american-family-agony-child-order-crossings/.

MASSEY, D. 1994. Space, Place and Gender. Minneapolis: Minnesota UP.

1995. "The conceptualization of place." A Place in the World? Eds. D. Massey and P. Jesse. New York: Oxford UP. 45-86.

MASSEY, D., J. DURAND AND N. J. MALONE. 2002. Beyond Smoke and Mirrors: Mexican Immigration in the Era of Economic Integration. New York: Russell Sage Foundation.

MCDOWELL, L. 2003/1999. Gender, Identity and Place: Understanding Feminist Geographies. Minneapolis: Minnesota UP.

NEVINS, J. 2002. Operation Gatekeeper: The Rise of the "Illegal Alien" and the Making of the U.S.-Mexico Boundary. New York and London: Routledge.

O'BRIEN, E. 2008. The Racial Middle: Latinos and Asian Americans Living Beyond the Racial Divide. New York and London: New York UP.

OECD. 2012. “International Migration Outlook 2012.” OECD Publishing. 16 July. 2014. http://www.npdata.be/BuG/165-NV-A-migratie/0ECD-Migration-Outlook-2012.pdf.

OMI M. AND H. WINANT. 1994. Racial Formation in the United States: From the 1960s to the 1990s. New York: Routledge.

OTSU, K. 1997. Development of Teaching Materials for Global Integrated Learning. Tokyo: Meiji Tosho.

PARK, H. 2014. "Children at the Border.” The New York Times. 13 Oct. 2014. http:// www.nytimes.com/interactive/2014/07/15/us/questions-about-the-border-kids. html?_r=1.

PÉREZ HUBER, L, C. BENAVIDES LOPEZ, M. MAGALON, V. VELEZ, AND D. SOLOZARNO. 2008. "Getting Beyond the 'symptom,' acknowledging the 'disease': Theorizing racist nativism.” Contemporary Justice Review 11: 39-51. 
Pyke, K. D. "Immigrant Families and the Shifting Color Line in the United States." The Wiley-Blackwell Companion to the Sociology of Families. Eds. J. Treas, J. Scott and M. Richards. Chichester: John Wiley \& Sons. 194-216.

RADEL, C., B. SCHMOOK AND S. MCCANDLES. 2010. "Environment, transnational labor migration, and gender: Case-studies from Southern Yucatán, Mexico and Vermont, USA.” Popul Environ 32: 177-197.

ROSE, G. 1995. "Place and identity: a sense of place." A Place in the World? Eds. D. Massey and P. Jesse. New York: Oxford UP. 87-132.

ROSENBLUM, M. R., W. A. KANDEL, C. R. SEELKE AND R. E. WASEM. 2012. "Mexican Migration to the United States: Policy and Trends." Congressional Research Service. 17 July. 2014. http://fas .org/sgp/crs/row/R42560.pdf.

SASSEN, S. 1996. "U.S. Immigration Policy toward Mexico in a Global Economy." Between Two Worlds: Mexican Immigrants in the United States. Ed. D. G. Gutiérrez. Wilmington: Scholarly Publishers. 213-228.

1998. Globalization and its Discontents: Essays on the Mobility of People and Money. New York: New York UP.

2013/1991. The Global City: New York, London, Tokyo. Princeton: Princeton UP.

SCHRAG, P. 2010. Not Fit for Our Society: Immigration and Nativism in America. Berkeley: University of California Press.

SIBLEY, D. 2002/1995. Geographies of Exclusion: Society and Difference in the West. London and New York: Routledge.

SUÁREZ-OROZCO, M. 2001. "Globalization, Immigration and Education: The Research Agenda." Harvard Educational Review 71, 3: 345-365.

VANDERBECK, R. M. 2006. "Vermont and the Imaginative Geographies of American Whiteness." Annals of the Association of American Geographers 96, 3: 641-659.

WHITE, L., H. SMITH AND C. CURRIE. 2011. "OR in Developing Countries: a Review.” European J. Opl Res 208, 1: 1-11.

WORLD POPULATION STATISTICS. N.D. "VERMONT POPULATION 2013.” 28 May. 2014. http://www.worldpopulationstatistics.com/vermont-population-2013/ 